\title{
Entrepreneurial Skills and SME's Business Performance: Empirical Study Culinary Business
}

\author{
Widji Astuti, Fajar Supanto, Bambang Supriadi \\ Lecture of Management Department, Economics Faculty, University Of Merdeka Malang
}

\begin{abstract}
This study aims to investigate the relationship and the influence of entrepreneurial skill on business performance. The quantitative research data type was based on a questionnaire. Populasion is SME's entrepreneur, who are members of the food and beverage sub-sector community in Malang City, 300 SMEs. The sample size is 181 entrepreneurs of SMEs food and beverage on chips as the sub sectors were made using the simple random sampling technique. The Results of this study indicate that the relationship and influence of entrepreneurial skills with business performance SME's is small. Personal Maturity skill have a major contribution of entrepreneurial skill on business performance SME's. In conclusion, managerial skills developed becomes more responsible as marketing strategy plan, implementation and follow-up should be developed by researchers in the future, observing variables like entrepreneurial characteristics, entrepreneurship motivation, entrepreneurship orientation, market orientation, innovation and knowledge sharing as business performance predictions
\end{abstract}

Key words : Marketing Performance, SMEs, Entrepreneurial Skills.

DOI: $10.7176 / \mathrm{JESD} / 10-22-17$

Publication date: November $30^{\text {th }} 2019$

\section{Introduction}

SMEs are proven to contribute significantly to the national economy in job creation, employment because it has a high entry barrier, especially in the food and beverage sub-sector. On the other hand, SMEs to ensure business continuity are required to have entrepreneurial skills to develop business amid rapid environmental changes and intense competition (Lee, 2018). Theoretical implications, entrepreneurial skills become capital in managing resources in producing business performance.

However, several studies have shown that entrepreneurial individuals and organizations can differ in their characteristics (Bromiley and Fleming, 2002; Lee and Tsang, 2001; Lee, 2019), which are currently patterned on technical skills, technology grants, capital and technical-management training, and have not been patterned on performance and sustainable entrepreneurship. The gap between the needs of entrepreneurship and entrepreneurship development programs. This is a gap to study entrepreneurial skills in producing business performance in a culinary business (Food and Beverage).

\section{Literature Review}

\subsection{Business Performance}

Business competition of small, medium and large businesses is not distinguish. All three business sizes compete for the same market share. Performance is a common construct to measure the impact of corporate strategy implementation. Research shows that performance measurement becomes both a classic problem and debate because performance is a multidimensional construct are both empirical and theoretical (Hakala, 2013). Further research has developed various measures of business performance, Hadji, Monales and Dickson (2000) measure business performance (BP) using increased sales, employee satisfaction, profitability, and increased market growth. Kirca et.al (2005), by measuring customer satisfaction, employee satisfaction, sales growth, and profitability. In the Lumpkin and Dess (2012) study, business performance is measured from the financial dimension supported by financial investment and sales growth indicators, while the non-financial performance dimension measures customer satisfaction. Indicators developed by Sorensen and Chang (2006): sales volume, revenue, sales growth, revenue growth, and organizational growth. For Lee and Tsang (2013), business performance was measured by three indicators, namely sales growth, profit growth and capital growth. The dimensions of performance measurement used in SMEs studies are growth, profitability, and productivity.

\subsection{Entrepreneurial Skills}

Entrepreneurship is a multifaceted phenomenon. Therefore, entrepreneurship is not only the process of obtaining business; the essence of work as an agent of change. Entrepreneurship in the view of Man et al. (2002), 
as competencies or characteristics that are complemented by personality, skills and knowledge characteristics. Bird (1995) which describes entrepreneurship "as a trait that underlies generic and specific knowledge, motives, traits, self-image, social roles, and skills that produce births, life struggles, and / or business growth." Likewise, Kao's view (1995) states that the process of making it is the creation of new works, something different.

In a broad sense, entrepreneurs must equip themselves with learning competencies that support them to assist in managing the business. Skillful in managing a business. Companies that support success or company are needed by competence and competence (Bird, 1995). This view, because entrepreneurial competence is carried out by individuals as entrepreneurs who start and transform organizations by adding value through the organization of resources and opportunities. So, Entrepreneurial skills are abilities that drive attitude changes to be able to have skills, create their own results, and solve problems, on an ongoing basis.

Entrepreneurial skills are an illustration of entrepreneurial competence. Competence in entrepreneurial skills is the key to successfully starting business diversification and sustainable profitability. Several studies have developed indicators of Entrepreneurial skills, Kutzhanova et al (2009) identified four dimensions of Entrepreneurial skills: (1) Technical Skills; (2) Managerial Skills, (3) Entrepreneur Skills; (4) Personal Maturity Skills. Previously in 2007, Smith, Schallenkamp and Eichholz developed 4 skill categories, namely technical skills, managerial skills, entrepreneurial personal skills, and personal maturity skills. Mohammad Salman Shabbir, et al., (2016) developed entrepreneurial skills set as a determinant of business success consisting of technical skills, managerial skills, leadership skills, entrepreneurial personal skills, and personal maturity skills. In subsequent studies this category is a measure of entrepreneurial skills that must be continuously studied / developed in selfemployment in ensuring business continuity.

\section{The Relationship Entrepreneurial Skills and Business Performance.}

The studies have discussed entrepreneurial skills and business performance. Research on performance that requires entrepreneurship provides results that are still debatable. Research findings that support entrepreneurship contribute to and impact on business performance are examined by Covin and Slevin, 1991; Lumpkin and Dess, 2001; Wiklund, and Shephered, 2005; Shabbir Salman, et al, (2016). However, different from the findings of Hastin's research (2010), Muthalib,.2014, and Inna (2016), with the results of entrepreneurship not directly affecting business performance.

Based on the conception and development of the study, it can be illustrated in the research framework :

Figure 1. Conceptual Framework

\begin{tabular}{|c|}
\hline $\begin{array}{c}\text { Entrepreneurial Skills } \\
\text { technical skills, } \\
\text { managerial skills, } \\
\text { leadership skills, } \\
\text { entrepreneurial personal skills, personal } \\
\text { maturity skills }\end{array}$ \\
\hline $\begin{array}{c}\text { Business Performance } \\
\text { Sales Growth } \\
\text { Customer Growth } \\
\text { Profitability Growth }\end{array}$ \\
\hline
\end{tabular}

\section{Hypothesis:}

1) Managerial skill have a major apreciation of entrepreneurial skills on business performance

2) Strong and positive relationship between Entrepreneurial skills and business performance

3) Entrepreneurial skills as technical skill, managerial skill, leadership skill, personal skill and entrepreneur personal maturity has a positive and significant impact on business performance

\section{Method}

The questionnaires consisted of 39 items split between three instruments that each measured business performance (11-items are based on Sanchez and Marin, 2005), and entrepreneurial skills (28-item). These instruments consist of a five-item scale described at either end by "strongly agree" and "strongly disagree". The target popular was the entrepreneurs of SMEs in the food and beverage sector, because this sector has the ability to absorb $66.8 \%$ of the workers in Malang. The selection of the city of Malang as the object of research is megacities with 3 destinations namely the city of education, industry and tourism. The food and beverage subsector developed into a supporter of tourism. The sample was 181 entrepreneurs of SMEs in the food and beverage 
sector, who have been running a business for at least 3 years, who have a business performance description and are incorporated in the community as SMEs in the food and beverage sector, based on simple random sampling techniques. The research analysis was conducted using a simple linear regression.

\section{Result}

Research testing began with a test of validity and reliability. The instrument tests used on the question items have been concluded as being valid (see Table 1.). The results obtained from each coefficient value reliability were entrepreneurial skills $=0.909>0,06$ and business performance $=0.601>0,06$. So, The research instrument used in this study is reliable and can be used as a measuring instrument.

Table 1. Validity

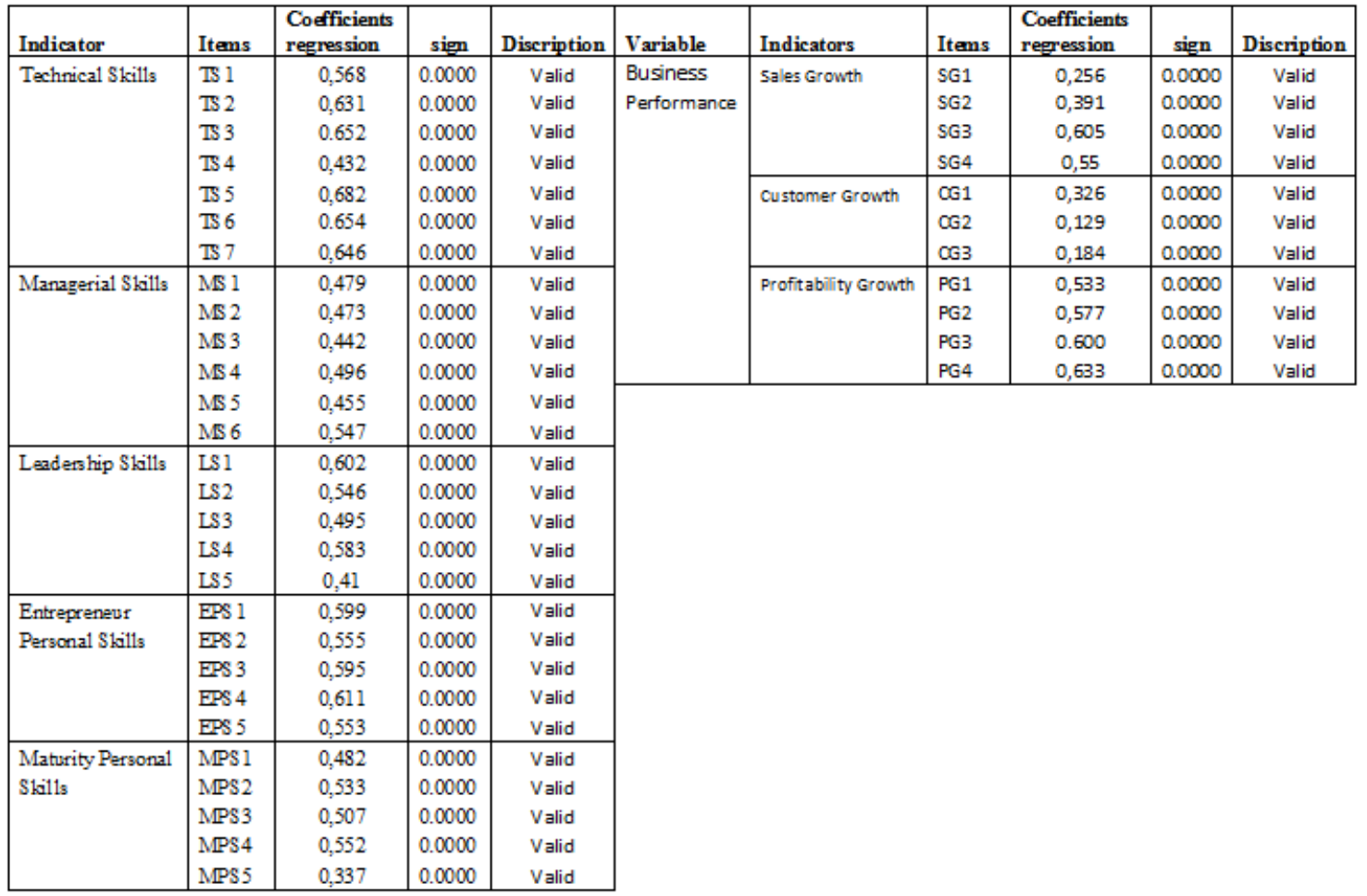

\subsection{Model Analysis and Hypothesis Testing}

First test, the data in meeting the eligibility requirements of a simple linear regression model with the Classic assumption test :

\subsubsection{Normality Test}

The following SPSS output table is obtained sign $=0.907>0.05$. Thus the normality requirements in the model have been met. 
Table 2.

One-Sample Kolmogorov-Smirnov Test

\begin{tabular}{|c|c|c|}
\hline & & $\begin{array}{l}\text { Unstandardiz } \\
\text { ed Residual }\end{array}$ \\
\hline$N$ & & 181 \\
\hline \multirow[t]{2}{*}{ Normal Parameters ${ }^{a \cdot b}$} & Mean & OE- 7 \\
\hline & Std. Deviation & 4.09818912 \\
\hline \multirow[t]{3}{*}{ Most Extreme Differences } & Absolute & .042 \\
\hline & Positive & .034 \\
\hline & Negative & -.042 \\
\hline Kolmogorov-Smirnov Z & & .565 \\
\hline Asymp. Sig. (2-tailed) & & .907 \\
\hline
\end{tabular}

a. Test distribution is Normal.

b. Calculated from data.

\subsubsection{Autocorelations Test}

Based on table 3, Durbin Watson's calculated value $(4-1.569=2.431)>$ Durbin Watson's table value $(1.768)$, so it can be concluded that there is no autocorrelation.

\section{Table 3. Result Autocorelations Test Model Summary}

\begin{tabular}{|l|r|r|r|r|r|}
\hline Model & R & R Square & $\begin{array}{c}\text { Adjusted R } \\
\text { Square }\end{array}$ & $\begin{array}{c}\text { Std. Error of } \\
\text { the Estimate }\end{array}$ & \multicolumn{1}{c|}{$\begin{array}{c}\text { Durbin- } \\
\text { Watson }\end{array}$} \\
\hline 1 & $.161^{\mathrm{a}}$ & .026 & .020 & 4.110 & 1.569 \\
\hline
\end{tabular}

a. Predictors: (Constant), X1

b. Dependent Variable: $Y$

\subsubsection{Heteroscedasticity Test.}

The output results presented in table 4 , the significance value $=0.115>0.05$, no symptoms of heteroscedasticity.

Table 4. Result Heteroskedastisity Test

Coefficients $^{a}$

\begin{tabular}{|c|c|c|c|c|c|c|}
\hline \multirow{2}{*}{\multicolumn{2}{|c|}{ Model }} & \multicolumn{2}{|c|}{ Unstandardized Coefficients } & \multirow{2}{*}{$\begin{array}{c}\text { Standardized } \\
\text { Coefficients }\end{array}$} & \multirow[b]{2}{*}{$t$} & \multirow[b]{2}{*}{ Sig. } \\
\hline & & $\mathrm{B}$ & Std. Error & & & \\
\hline & (Constant) & -1.194 & 1.729 & & -.690 & .491 \\
\hline & $\mathrm{X} 1$ & .024 & .015 & .118 & 1.584 & .115 \\
\hline
\end{tabular}

a. Dependent Variable: LNUI2

Classic assumption tests are met, then hypothesis testing is performed.

\subsection{Hypothesis Testing}

\subsubsection{Hyphotesis 1 .}

Descriptive analysis of mean indicators is used to prove managerial skills are most appreciated in entrepreneurial skills. The results of the mean entrepreneurial skill indicators in table 5, showing the maturity of SME entrepreneurs are major appreciated, because the biggest mean. H1 is not proven. 
Table 5. Result Mean Indicators Entrepreneurial Skills

\begin{tabular}{|c|c|}
\hline Indic ators & Mean \\
\hline Technical Skills & 4,04 \\
\hline Managerial Skills & 3,77 \\
\hline Leadership Skills & 4,08 \\
\hline Entrepreneurship Personal Skills & 4,13 \\
\hline Personal Maturity Skills & 4,20 \\
\hline Entrepreneurial Skills & 4,04 \\
\hline
\end{tabular}

\subsubsection{Hypothesis 2 .}

The result of data processing with simple linear regression, obtained R Square of 0,026 , it means that the strength and direction of the relationship between entrepreneurial skills and business performance is weak and positive. Thus hypothesis 2 is not fully tested. This indicates the strength of the relationship between entrepreneurial skills and business performance is weak (2.06\%), because $97.94 \%$ is actually influenced outside skilled in entrepreneurship

\subsubsection{Hypothesis 3 .}

Based on the table of simple linear regression results :

Table 6. Result Simple Linear Regression

Coefficients $^{\text {A }}$

\begin{tabular}{|c|c|c|c|c|c|c|}
\hline \multirow{2}{*}{\multicolumn{2}{|c|}{ Model }} & \multicolumn{2}{|c|}{ Unstandardized Coefficients } & \multirow{2}{*}{$\begin{array}{c}\text { Standardized } \\
\text { Coefficients } \\
\text { Beta } \\
\end{array}$} & \multirow[b]{2}{*}{$\mathrm{t}$} & \multirow[b]{2}{*}{ Sig. } \\
\hline & & $\mathrm{B}$ & Std. Error & & & \\
\hline & (Constant) & 34.116 & 3.207 & & 10.639 & .000 \\
\hline & $\mathrm{X} 1$ & .062 & .028 & .161 & 2.177 & .031 \\
\hline
\end{tabular}

a. Dependent Variable: $Y$

The results of the output regression significant (sign) at 0.031 , it means less than 0.05 , and the t test at 2.177 $>$ 1.973. Thus, entrepreneurial skills consisting of technical skills, managerial skills, leadership skills, entrepreneurial personal skills and personal maturity skills affect business performance positively and significantly, with the magnitude of influence of 0.062 . H3 tested.

\section{Discussion And Implications}

This study found that entrepreneurial skills affect SME's business performance, but the relationship between the two is weak, and weak managerial skills appreciate entrepreneurial skills but personal maturity skills are most appreciate. This finding is in line with previous research Widji Astuti (2007) that business development requires capital but SMEs most need managerial and technical skills; Lee (2018), that entrepreneurial characteristics namely hard workers was a significant predictor of venture success.

This indicates that SMEs entrepreneurs in the food and beverage sub-sector to become entrepreneurs are not a necessity but as an option, and decide to become entrepreneurs in food and beverage because food and beverage are daily needs and low in risk, because it is enough to have skills in gathering drinks and food. This finding is in line with previous research Widji Astuti $(2003,2005)$, that being an entrepreneur because there is no other choice, the entrepreneurial family, and the food and beverage business is the easiest and most risk-free. Implications for business, customer and sales performance are growing, but have not been able to grow profits. Entrepreneurs may be able to run their business longer because of their entrepreneurial experience, but are very vulnerable to environmental changes that occur if they don't have managerial skills. Managerial skills make entrepreneurs master change and are able to adapt to change because they have the intuition and ability to plan, implement and control and evaluate their business performance in the long run, because they are able to see market opportunities. With the market opportunity entered, it provides profitability, as Narver and Slater (1990), Morgan and Mason (2009), Mitchelmore and Rowley (2013) argues. 


\section{Conclusion}

Indonesia is very rich with local culinary. In order to support regional tourism, culinary can be one of the tourist destinations. On the other hand the growth of entrepreneurship can be one way out of job creation. However, it needs a guidance strategy and assistance based on needs. Entrepreneurial skills of the food and beverage subsector of SMEs still need guidance and assistance in terms of managerial and technical skills, because appreciation is very weak. Future research is very important to develop factors that influence business performance such as entrepreneurship motivation, entrepreneurship orientation, market orientation and innovation.

\section{Acknowledgement}

This research was made possible with funding from Ministry of Research, Technology and Higher Education of the Republic of Indonesia

\section{References}

Bromiley, P. and Fleming, L. (2002) 'The Resource Based View of Strategy: An Evolutionist's Critique', in M. Augier and J. March (eds) Economics of Choice, Change, and Organizations:Essays in Memory of Richard M. Cyert. Cheltenham: Edward Elgar.

Lee. Don Y., Tsang. Eric W. K., (2001), The effects of Entrepreneurial Personality, Background and Network Activities on Venture Growth, Journal of Management Studies, Volume 38, Issue 4, p. 583 - 602

Lee. Byungku, (2019), "Human capital and labor: the effect of entrepreneur characteristics on venture success", International Journal of Entrepreneurial Behavior \& Research, Vol. 25 No. 1, p. 29-49

Hakala, H. (2013). Entrepreneurial and Learning Orientation: Effects on Growth and Profitability in The Software Sector. Baltic Journal of Management, 8(1), p.102-118

Hadjimonalis, Anthanasios., Keith Dickson (2000), Innovation Strategies of SMEs in Cyprus, A Small Developing Country, International Small Business Journal. 18,4, p. 62-79 Kirca et.al.,2005.

Lumpkin, GT dan Dess, GG (2001), Linking Two Dimensions of Entrepreneurial Orientation to Firm Performance: The Moderating Role of Environment and Industry Life Cycle, Journal of Business Venturing, 16, p. 429-451.

Sørensen, J.B. and Change, P.M.T. (2006), "Determinants of successful entrepreneurship: a review of the recent literature”, available at: http://ssrn.com/abstract1/41244663 (accessed June 29, 2011).

Man, T. W. Y., Lau, T., \& Chan, K. F. (2002). The Competitiveness of small and medium enterprises - A conceptualization with focus on entrepreneurial competences. Journal of Business Venturing, 17, p.123-142.

Bird, B. J. (1995). Toward a theory of entrepreneurial competency. Advances in Entrepreneurship, Firm Emergence, And Growth., Vol. 2, p.51-72.

Kao, R.W.Y. (1995), Entrepreneurship: A wealth Creation and Value Adding Process, Prentice Hall Singapore.

Kutzhanova, N., Lyons, T.S. \& Lichtenstein, G.A. (2009) -Skill-Based Development of Entrepreneurs and the Role of Personal and Peer Group Coaching in Enterprise Development, Economic Development Quarterly, Vol. 20, No.10 .

Smith, W L., Schallenkamp, K., and Eichholz, D.E. (2007). Entrepreneurial skills assessment: an exploratory study. International Journal of Management and Enterprise Development, 4(2), p. 179-201

Salman, Mohammad Shabbir, Mohd Noor Mohd Shariff, Arfan Shahzad, (2016), Determinants of Entrepreneurial Skills set in Pakistan: A Pilot Study, International Journal of Academic Research in Accounting, Finance and Management Sciences, Vol. 6, No.2, p. 76-86Covin and Slevin, 1991; 
Lumpkin, GT dan Dess, GG (2001), Linking Two Dimensions of Entrepreneurial Orientation to Firm Performance: The Moderating Role of Environment and Industry Life Cycle, Journal of Business Venturing, 16, p. 429-451.

Wiklund, \& Sepherd, D., (2005). Entrepreneurial Orientation and Small Business Performance: A configurational approach. Juornal of Business Venturing, 20(1), p. 71-91.

Salman, Mohammad Shabbir, Mohd Noor Mohd Shariff, Arfan Shahzad, (2016), Determinants of Entrepreneurial Skills set in Pakistan: A Pilot Study, International Journal of Academic Research in Accounting, Finance and Management Sciences, Vol. 6, No.2, p. 76-86Covin and Slevin, 1991;

Hastin, (2010), in Muthalib, Abd. Azis.2014. Entrepreneurship and its Impact on Business Performance Improvement and Poverty Reduction (An Empirica Study Micro Business Industrial Sector in Kendari). International Journal of Humanities and social science invention. Volume 3 Isuue Oktober 2014.p.55-65

Muthalib, Abd. Azis.2014. Entrepreneurship and its Impact on Business Performance Improvement and Poverty Reduction (An Empirica Study Micro Business Industrial Sector in Kendari). International Journal of Humanities and social science invention. Volume 3 Isuue Oktober 2014.p.55-65

Inna Kozlinska, (2016), Evaluation of The Outcomes of Entrepreneurship Education, Disertation, Repository Turun Yliopiston Julkaisuja - Annales Universitatis Turkuensis.

Widji, Astuti (2003), Theoretical Study of the Concept of Independence and Entrepreneurship Relation to Student Creater Job, Repository, Unmer Malang.

Widji, Astuti (2005), Gender-specific Entrepreneurship Learning Model for Wives TKI Male, Repository, Unmer Malang.

Widji, Astuti (2007), Theoretical Study of the Concept of Business Independence in Relation to Providing Small Business Capital Assistance for the Informal Sector in Malang City, Repository, Unmer Malang

Narver, J.C. and Slater, S.F. (1990), “The effect of a market orientation on business profitability”, TheJournal of Marketing, Vol. 54 No. 4, pp. 20-35.

Morgan, R.E. and Strong, C.A. (2003), “Business performance and dimensions of strategic orientation”,Journal of Business Research, Vol. 56 No. 3, pp. 163-176.

Mitchelmore, S. and Rowley, J. (2013), “Entrepreneurial competencies of women entrepreneurs pursuingbusiness growth”,Journal of Small Business and Enterprise Development, Vol. 20 No. 1,pp. 125-142. 